\title{
Investigating Work Conditions and Burnout at Three Hierarchical Levels
}

\author{
Daniel Lundqvist, Cathrine Reineholm, Maria Gustavsson and Kerstin Ekberg
}

\section{Linköping University Post Print}

\section{Tweet}

N.B.: When citing this work, cite the original article.

Original Publication:

Daniel Lundqvist, Cathrine Reineholm, Maria Gustavsson and Kerstin Ekberg, Investigating Work Conditions and Burnout at Three Hierarchical Levels, 2013, Journal of Occupational and Environmental Medicine, (55), 10, 1157-1163.

http://dx.doi.org/10.1097/JOM.0b013e31829b27df

Copyright: Lippincott, Williams \& Wilkins

http://www.lww.com/

Postprint available at: Linköping University Electronic Press

http://urn.kb.se/resolve?urn=urn:nbn:se:liu:diva-95575 


\title{
Investigating Work Conditions and Burnout at Three Hierarchical Levels
}

\author{
Daniel Lundqvist, MSSc, Cathrine Reineholm, MPH, Maria Gustavsson, PhD, \& \\ Kerstin Ekberg, PhD
}

From the HELIX VINN Excellence Centre (Mr Lundqvist, Mrs Reineholm, Drs Gustavsson and Ekberg), National Centre for Work and Rehabilitation, Department of Medical and Health Sciences (Mr Lundqvist, Mrs Reineholm and Dr Ekberg), Department of Behavioural Sciences and Learning (Dr Gustavsson), Linköping University, Sweden

Conflict of Interest and Source of Funding

The authors have no conflicts of interest to report.

This work was funded by HELIX VINN Excellence Centre, Linköping University, Sweden.

Address correspondence to Daniel Lundqvist, HELIX VINN Excellence Centre, Hus Terra, 58183 Linköping, Sweden (daniel.lundqvist@liu.se). 
Investigating work conditions and burnout at three

\section{Investigating Work Conditions and Burnout at Three Hierarchical Levels}

Objective: To investigate the differences in work conditions and symptoms of burnout, and the association between work conditions and symptoms of burnout at the three hierarchical levels: subordinates, first-line managers and middle managers. Methods: Analyses were based on questionnaire data from 4096 employees in nine organizations, containing three hierarchical levels: subordinates $(n=3659)$, first-line managers $(n=345)$, and middle managers $(n=92)$. Results: Work conditions were found to differ between the three hierarchical levels, mostly between subordinates and managers. Managers experienced fewer symptoms of burnout than subordinates. Furthermore, the association between work conditions and burnout differed for subordinates, first-line managers and middle managers. Conclusions: Occupational health research needs to focus more on differences between hierarchical levels regarding work conditions and burnout. 


\section{INTRODUCTION}

The relation between work conditions and burnout has been thoroughly investigated, ${ }^{1-3}$ but little attention has been paid to differences between hierarchical levels in organizations regarding this relation. Some studies suggest that managers and subordinates have different work conditions, but the association between work conditions and burnout is rarely compared. Managers usually experience higher demands, ${ }^{4,5}$ more conflicts at work ${ }^{5}$ and more conflicts between work and private life $^{6}$ than subordinates. Managers also experience higher control, higher autonomy, more influence, more freedom at work, ${ }^{4,5,7,8}$ and more social support than subordinates. $^{4,9}$

Managers are generally found to have better health than subordinates. ${ }^{10-13}$ Some studies have also found that managers experience less stress than subordinates. ${ }^{5,9}$ Differences in health or stress between managers and subordinates are usually explained in terms of managers having more influence and more opportunities for adjusting their work. ${ }^{5,14}$ Thus, although managers have very demanding work, they also have more control, influence and information than subordinates do, and it is supposed that this mitigates the effect of their experienced demands.

A problem in previous research is that managerial levels are rarely differentiated, even though some studies have shown that managers at different managerial levels have different work tasks. ${ }^{15-17}$ The work tasks of first-line managers tend to be operational, short term, and focused on facilitating the work tasks of subordinates; while middle managers' work tasks tend to be more strategic, long term and focused on facilitating the work groups' performance. ${ }^{15,16,18}$ The higher the managerial level, the more opportunities there are to adjust the assignment. Middle managers have more resources, more information ${ }^{19}$ and higher autonomy than first-line managers, ${ }^{20}$ which decreases stress and increases health. ${ }^{21-23}$ Middle 
managers perceive conflicting demands as important for their health and stress; while reward, recognition, control and possibility to influence are important for first-line managers' health. ${ }^{24,25}$ Also, managers in higher managerial levels have better health than managers in lower managerial levels. ${ }^{13}$

Despite research showing that employees at different hierarchical levels have different work conditions, the association between work conditions and ill-health is rarely studied with designs that enable comparisons between hierarchical levels in the same organizations. For instance, managers and subordinates may experience the same degree of role ambiguity, but it is experienced as more stressful for managers. ${ }^{26}$ Instead, it is generally presumed that work conditions have the same importance, regardless of hierarchical level. An exception is Cooper and Bramwell's ${ }^{6}$ study on brewing personnel in Scotland. They compared the associations between work conditions, job satisfaction and health for subordinates and first-line managers. Their results showed that the same work conditions were associated with job satisfaction for both subordinates and first-line managers, and that some work conditions were differently associated with managers' health than with subordinates' health. However, their study was undertaken in one particular organization with a low response rate. Furthermore, they only included managers at one managerial level.

Considering these issues, the objective of this study is threefold: (1) to compare the differences in work conditions in three hierarchical levels: subordinates, first-line managers and middle managers; (2) to compare symptoms of burnout between subordinates, first-line managers and middle managers; and (3) to investigate if the association between work conditions and burnout differs for subordinates, first-line managers and middle managers.

\section{METHOD}


Investigating work conditions and burnout at three

\section{Sample and procedures}

The material was based on questionnaire data from nine different organizations in Sweden: four municipalities, one industrial company, two governmental agencies, one hospital and one private healthcare company. The researchers contacted representatives in each organization and asked if they were interested in participating in the study. Organizations from different sectors were selected to ensure variety of the material. If they agreed to participate, questionnaires were sent to their employees $(\mathrm{N}=6841)$. For confidentiality purposes, each respondent sent the completed questionnaire back to the researchers. A reminder was sent after two seeks, and a second reminder after another two weeks. A total of 4096 employees (60\%) responded to the questionnaire. The organizations' response rate varied between 52 percent and 78 percent. Of the respondents, 3659 were subordinates, 345 first-line managers and 92 middle managers. The response rate for subordinates was 57 percent, for first-line managers 84 percent, and for middle managers 74 percent (Table 1). In this study, a manager was defined as an employee with personnel and budgetary responsibilities. A first-line manager had at least one subordinate without managerial responsibilities, while a middle manager had at least one subordinate with managerial responsibilities. All questionnaires were coded so that each respondent was connected to the organization in which they were working, to their hierarchical level, and to their immediate manager. This coding procedure made it possible to follow the hierarchical order in each organization, and thereby control for potential bias of heterogeneity in organizations and work groups of each hierarchical level.

\section{Ethics}

Ethical principles for social science have been fulfilled. The study was approved by the Ethics Committee at Linkoping University. 


\section{Measures}

\section{Work conditions}

The work condition variables were demands (5 items) and control (6 items) from the Job Demand Control (JDC) model by Karasek and Theorell, ${ }^{27}$ relating to mental workload and the ability to use and develop skills. One example item capturing demands is: "Do you have to work very fast?". The response scale ranges from Yes, often (1) to No, never (4). Cronbach's alpha for demands was .80 and for control .70. Social capital at work (8 items) captures efficacy of social capital, indicating whether people feel respected, valued and treated as equals. ${ }^{28}$ One example item is: "People feel understood and accepted by each other", ranging from Fully disagree (1) to Fully agree (5). Cronbach's alpha for social capital was .90. Scales on role clarity (3 items), role conflict ( 3 items), and interactions between work and private life (2 items) were taken from the QPS Nordic. ${ }^{29}$ One example item capturing role conflict is: "Do you have to do things that you feel should be done differently?" and the response scale ranged from Very seldom or never (1) to Very often or always (5).Cronbach's alpha for role clarity was .75 , for role conflict .66 and for interactions between work and private life .63. Information regarding span of control was provided from the organizations.

The three items used to investigate opportunities to adjust work, e.g. when feeling out of sorts, were: "Can you work at a slower pace?", "Can you shorten the workday?" and "Can you get help from work colleagues?". ${ }^{30}$ The response scales ranged from Always (1) to Seldom/never (3).

\section{Burnout}

Symptoms of burnout were measured by the generic part of the Copenhagen Burnout Inventory $(\mathrm{CBI}) .{ }^{31}$ The scale is intended to answer the question "How tired or exhausted are 
you?", and the response scale is a 5-point Likert scale $(1=$ Always, $5=$ Never/almost never $)$. Cronbach's alpha for burnout was .89. The range of the scale is $0-100$, where the first category (always) is scored 100 and the fifth category (never/almost never) is scored 0.

\section{Control variables}

Sex, age, and education level were used as control variables, as previous research has shown that these factors are associated with self-rated health. ${ }^{32-35}$ The respondents in the material belonged to different work groups, worked in different organizations and in different sectors. To control for the possible effect of these differences, three nested variables were created: 1) the subordinates and their managers were matched, 2) first-line managers and their managers were matched, 3) middle managers and their organization were matched. By using these variables we focus on differences in hierarchical levels, rather than differences between work groups or organizations, and our results thus become more generalizable.

\section{Statistical analysis}

Differences in demographics between subordinates, first-line managers and middle managers were examined using chi-square test and Fisher's exact test.

The distribution of the means and standard deviations for work conditions and burnout among subordinates, first-line managers and middle managers were calculated using ANOVA. The Games-Howell post hoc-test was used due to the unequal sample sizes.

The relationship between the variables was examined using Pearson correlation analysis.

To investigate the associations between work conditions and burnout, multiple linear regressions were performed (method Enter). To ensure validity of the multiple regression 
models, power was calculated. According to the test, power was satisfactory $(>.97)$ for the three hierarchical groups. ${ }^{36}$

Missing scores on single questions was handled in accordance with previous research. ${ }^{37} \mathrm{~A}$ total score was calculated for a person if the person has answered at least half of the questions of the scale. The missing items were given the average score of the other items in the scale. SPSS Version 19.0 (Armonk, NY: IBM Corp) was used for statistical analysis.

\section{RESULTS}

\section{Descriptive statistics}

Demographic factors are presented in Table 1. In total, there were more women (66\%) than men (34\%). The total mean age was 47.2 years. The mean age was $47.3,47.1$ and 46.5 for subordinates, first-line managers, and middle managers respectively.

Nearly half of the respondents (48\%) had a secondary education. A university degree was held by most $(85 \%)$ of the middle managers, half $(52 \%)$ of the first-line managers and 42 percent of the subordinates.

\section{Non-response analysis}

Differences between respondents and non-respondents were analysed on available data (sex and age). Respondents ( $M: 47.08 ; S D: 11.21)$ were older than non-respondents $(M: 43.66$; $S D: 16.13)(t(6725)=10.26, p<.001)$. There were no significant differences between the sexes.

[Insert Table 1 about here] 


\section{Correlations}

Correlations between all variables for measuring work conditions and burnout are presented in Table 2. In general, correlations were low, but significant. Highest correlations were found between demands and role conflict $(r=.53, p<.01)$, interactions between work and private life and burnout $(r=.47, \mathrm{p}<.01)$, and demands and interactions between work and private life $(r=.43, p<.01)$.

[Insert Table 2 about here]

\section{Differences in work conditions and burnout}

Work conditions and burnout were compared between subordinates, first-line managers and middle managers across the organizations (Table 3). The result showed that managers rated demands $(p=.002)$, control $(p<.001)$ and social capital $(p<.001)$ as significantly higher than subordinates, while no difference were found between first-line managers and middle managers. There were no differences in role clarity and role conflict between the three hierarchical levels. Middle managers rated interactions between work and private life $(p<$ .001) as significantly higher compared to subordinates and first-line managers. First-line managers had a larger span of control than middle managers $(p<.001)$.

Regarding opportunities for adjusting work, significant differences were found between subordinates and middle managers. Middle managers had more opportunities to work at a slower pace than subordinates $(p=.001)$, while subordinates had more opportunities to get 
help from work colleagues $(p=.045)$. Middle managers also had more opportunities to shorten their workday $(p<.001)$ than both subordinates and first-line managers. Subordinates had higher level of burnout symptoms than managers $(p<.001)$, while no differences were found between first-line and middle managers.

[Insert Table 3 about here]

\section{Associations between work conditions and burnout}

Multiple linear regressions were used to investigate the relationship between the work condition variables and burnout (Table 4). For subordinates, interactions between work and private life $(p<.001)$, demands $(p<.001)$, and role conflict $(p<.001)$ were associated with more symptoms of burnout, while social capital $(p<.001)$, control $(p<.001)$ and opportunities to shorten the workday $(p=.004)$ were associated with fewer symptoms of burnout. For first-line managers, interactions between work and private life $(p<.001)$, demands $(p<.001)$, and opportunities to get help from work colleagues $(p=.004)$ were associated with more symptoms of burnout, while social capital $(p<.001)$ was associated with fewer symptoms of burnout. For middle managers, role conflicts $(p=.030)$, demands $(p$ $=.031)$ and opportunities to get help from work colleagues $(p=.027)$ were associated with more symptoms of burnout, while opportunities to shorten the workday $(p=.012)$ were associated with fewer symptoms of burnout. The explained variance was highest for middle managers $\left(R^{2}=.510\right)$ and lowest for subordinates $\left(R^{2}=.328\right)$. 


\section{DISCUSSION}

This study investigated the differences between subordinates, first-line managers and middle managers with regard to work conditions and symptoms of burnout respectively, and the associations between work conditions and burnout at the three hierarchical levels. The main contribution of this study is that the relationship between work conditions and burnout is found to differ at the three hierarchical levels.

\section{Hierarchical differences in burnout and work conditions}

The results showed that managers experienced fewer symptoms of burnout than subordinates did. This is in line with earlier research showing that managers generally have better health than subordinates. ${ }^{10-13}$ Managers have a demanding work situation, ${ }^{24,38,39}$ but their better health is often explained by managers having more resources to handle these demands than subordinates do. ${ }^{5,14}$ Compared with subordinates, the managers in our study experienced higher demands and more negative interactions between work and private life. Managers, particularly middle managers, also had more control, more social capital and more opportunities to adjust their work. As suggested in previous research, ${ }^{5,14}$ better control and social capital for managers may mitigate the negative effects of the demanding work conditions and result in fewer symptoms of burnout than for subordinates. The fact that it is possible for employees to adjust their work, e.g. when feeling out of sorts, constitutes an important resource to handle stress and a possible mediating factor between stress and health outcomes. ${ }^{40}$

\section{Hierarchical differences in the relation between work conditions and}

\section{burnout}


Our study further showed that the three hierarchical levels differed with regard to which work conditions were associated with symptoms of burnout. The three most important work conditions associated with burnout were the same for subordinates and first-line managers. The work conditions of middle managers that were associated with burnout differed somewhat from the other two.

For subordinates and first-line managers, interactions between work and private life were strongly associated with burnout. It is well-known that negative interactions between work and private life have detrimental effects on well-being and ill-health, ${ }^{41-43}$ while influence and autonomy over work has been shown to mitigate these effects. ${ }^{43}$ Managers, particularly middle managers, ${ }^{19,44}$ have more opportunities to adjust their assignments in order to handle demands in their private life. Subordinates have fewer such opportunities. Further, first-line managers and middle managers have different responsibilities, and different requirements for being present at work. First-line managers are responsible for daily work operations, and this requires that they are present in everyday work. ${ }^{15,16,18,24,44}$ Therefore they may be unable to take advantage of the adjustment opportunities available to them. ${ }^{45}$ In contrast, middle managers' work tasks are more strategic and long-term, which makes it easier for them to take a day off if necessary. ${ }^{25}$

Social capital and social support has been shown to reduce stress and strain. ${ }^{46-49}$ In our study, social capital was associated with fewer symptoms of burnout for subordinates and first-line managers. For middle managers, the association between social capital and burnout was not significant. Middle managers usually have fewer colleagues to turn to than for instance subordinates. Research on managers' networking also shows that they have many contacts outside their workplace ${ }^{50-52}$ However, social capital, as measured in this study, concerns capital within the workplace. Social capital at work may not be associated with fewer symptoms of burnout for middle managers as they rely on contacts outside their 
workplace, as indicated in other studies. ${ }^{51,52}$ Furthermore, our results showed that opportunities to get help from work colleagues were associated with more symptoms of burnout for both first-line and middle managers. Research has shown that supportive relations within the workplace can be problematic for managers, ${ }^{53,54}$ and may explain why help from colleagues within the workplace was related to more symptoms of burnout.

Role conflict was highly related to symptoms of burnout for middle managers. Role conflict has been emphasized as a common problem in working life, especially for managers. ${ }^{24,39,55,56}$ Our results suggest that role conflicts are equally present at all hierarchical levels, although they may have more impact on middle managers' burnout. Managers often take a buffer role to protect their subordinates. ${ }^{57,58}$ Thus, the role conflicts experienced by subordinates may be transferred to their managers for them to handle, thereby decreasing the importance of role conflicts for subordinates and increasing its importance for managers. Furthermore, there may be different types of role conflicts at different hierarchical levels. Managers are caught in a cross-pressure situation between superior managers and subordinates, ${ }^{24,55,59,60}$ and these two constituents are vital for the performance of managers' work tasks. ${ }^{24,44,58,61}$ Conflicts that arise between them have consequences for the managers' task fulfilment, which may result in increased symptoms of burnout. ${ }^{24,45}$ Subordinates' constituents may not affect their task fulfilment; the constituents may for instance be outside the organization, and are therefore less important for the subordinates' symptoms of burnout.

Surprisingly, span of control was not related to managers' burnout, despite the fact that this has been suggested as an important stressor for managers. ${ }^{24,62,63}$ Span of control may contribute to a larger support network, boundary spanning etc. that may buffer the negative outcomes. $^{64}$ 
In summary, our study shows that managers have reasonably similar work conditions, regardless of managerial level. The differences in work conditions and symptoms of burnout were mostly between subordinates and managers, and fewer differences were found between the two managerial levels. Despite these similarities, our results showed that different work conditions were associated with symptoms of burnout at different hierarchical levels. The work conditions associated with symptoms of burnout were similar for subordinates and firstline managers, while middle managers differed. The work tasks of first-line managers and subordinates are often interlinked; they often work in the same place and encounter the same problems. ${ }^{15,16,18,24,44}$ These similarities in the work may result in similar work conditions being related to symptoms of burnout. Middle managers, on the other hand, are often not as present in the daily work, their responsibilities are often more strategic and less operational, and the daily problems that first-line managers and subordinates have to solve tend to only involve the middle managers indirectly. Additionally, middle managers have better opportunities than first-line managers and subordinates to adjust their assignments to handle demands placed on them. Thus, managers at the two managerial levels have different work tasks and prerequisites for performing or accomplishing these work tasks, ${ }^{15,16,24}$ resulting in different work conditions being associated with symptoms of burnout.

\section{Limitations and future research}

This study was based on extensive material containing three hierarchical levels, and all respondents answered the same questionnaire. The questionnaire that was used consisted of well-established and validated instruments, providing opportunities to generalize the results. A limitation is that the material consists of self-reported data. Nonetheless, Härenstam et al. ${ }^{65}$ suggest that self-reported work conditions are similar to objectively measured work conditions. 
Investigating work conditions and burnout at three

The design of the study made it possible to match subordinates and their managers, allowing us to control for the possible effect of differences in organizations and work groups. However, the material was cross-sectional and the results should be interpreted as such. In order to strengthen our interpretations, longitudinal material is needed.

As different work conditions seem to be important for burnout at different hierarchical levels, future research should continue to investigate this relationship with particular focus on potential reasons or causes for these differences, for instance, by asking employees at different hierarchical levels to describe their work conditions and why they are important.

\section{Conclusions}

The results of our study imply that occupational health research needs to focus more on differences in work conditions and burnout, and the relation between them, at different hierarchical levels. Access to resources and opportunities to use them for handling stressful work conditions may vary depending on the employees' hierarchical level. Recognition of differences in hierarchical levels will clarify and improve risk assessments and the study of detrimental work conditions.

\section{REFERENCES}

1. Borritz M, Bültmann U, Rugulies R, Christensen KB, Villadsen E, Kristensen TS. Psychosocial work characteristics as predictors for burnout: Findings from 3-year follow up of the PUMA Study. J Occup Environ Med. 2005;47:1015-1025.

2. Cordes CL, Dougherty TW. A review and an integration of research on job burnout. Acad Manage J. 1993;18:621-656. 
3. Schaufeli WB, Bakker AB, Van Reenen W. How changes in job demands and resources predict burnout, work engagement, and sickness absence. J Organ Behav. 2009;30:893917.

4. Johansson G, Sandahl C, Hasson D. Role stress among first-line managers and registered nurses - A comparative study. J Nurs Manage. 2011; DOI: 10.1111/j.13652834.2011.01311.x.

5. Skakon J, Kristensen TS, Christensen KB, Lund T, Labriola M. Do managers experience more stress than employees? Results from the intervention project on absence and well-being (IPAW) study among Danish managers and their employees. Work. 2011;38:103-109.

6. Cooper CL, Bramwell RS. A comparative analysis of occupational stress in managerial and shopfloor workers in the brewing industry: Mental health, job satisfaction and sickness. Work Stress. 1992;6:127-138.

7. Frankenhaeuser M, Lundberg U, Fredrickson M, et al. Stress on and off the job as related to sex and occupational status in white-collar workers. J Organ Behav. 1989;10:321-346.

8. Steptoe A, Willemsen G. The influence of low job control on amulatory blood pressure and perceived stress over the working day in men and women from the Whitehall II cohort. J Hypertension. 2004;22:915-920.

9. Wilkes B, Stammerjohn L, Lalich N. Job demands and worker health in machine-paced poultry inspection. Scand J Work Environ Health. 1981;7:12-19.

10. Kentner M, Ciré L, Scholl J. Psychosocial and clinical risk factor profiles in managers. Int Arch Occup Environ Health, 2000;73:S33-S40. 
11. Macleod J, Davey Smith G, Metcalfe C, Hart, C. Is subjective social status a more important determinant of health than objective social status? Evidence from a prospective observational study of Scottish men. Social Sci Med. 2005;61:1916-1929.

12. Marmot MG, Smith GD. Health inequalities among British civil servants: The Whitehall II study. Lancet. 1991;337:1387-1393.

13. Muntanez C, Borrell C, Benach J, PasarinMI, Fernandez E. The associations of social class and social stratification with patterns of general and mental health in a Spanish population. Int J Epidemiol. 2003;32:950-958.

14. Bernin P, Theorell T. Demand-control-support among female and male managers in eight Swedish companies. Stress Health. 2001;17:231-243.

15. Kraut AI, Pedigo PR, McKenna DD, Dunette MD. The role of the manager: What's really important in different management jobs? Acad Manage Executive. 1989;3:286293.

16. Pavett CM, Lau AW. Managerial work: The influence of hierarchical level and functional specialty. Acad Manage J. 1983;26:170-177.

17. Van der Velde MEG, Jansen PGW, Vinkenburg CJ. Managerial activities among top and middle managers: Self versus others perceptions. J Appl Manage Studies. 1999;8:161-174.

18. Allan P. Managers at work: A large scale study of the managerial job in New York City government. Acad Manage J. 1981;24:613-619.

19. Izraeli E. The middle manager and the tactics of power expansion: A case study. Sloan Manage Rev. 1975;16:57-70. 
Investigating work conditions and burnout at three

20. Marzuki PF, Permadi H, Sunaryo I. Factors affecting job satisfaction of workers in Indonesian construction companies. J Civil Eng Manage. 2012;18:299-309.

21. Bakker AB, Demerouti E. Towards a model of work engagement. Career Develop Int. 2007;13:209-223.

22. Morgeson FP, Humphrey SE. The Work Design Questionnaire (WDQ): Developing and validating a comprehensive measure for assessing job design and the nature of work. $J$ Appl Psychol. 2006;91:1321-1339.

23. Pousette A, Johansson Hanse J. Job characteristics of ill-health and sickness absenteeism in different occupational types - A multigroup structural equation modeling approach. Work Stress. 2002;16:229-250.

24. Broadbridge A. Retail managers: Their work stressors and coping strategies. J Retailing Consumer Services. 2002;9:173-183.

25. Lundqvist D, Fogelberg Eriksson A, Ekberg K. Exploring the relationship between managers' leadership and their health. Work. 2012; 42:419-427.

26. Schuler RS. Role perception, satisfaction and performance: A partial reconciliation. $J$ Appl Psychol. 1975;60:683-687.

27. Karasek R, Theorell T. Healthy Work: Stress, productivity and the reconstruction of working life. New York: Basic Books; 1990.

28. Kuovonen A, Kivimäki M, Vahtera J, Oksanen T, Elovaino M, Cox T, et al. Psychometric evaluation of a short measure of social capital at work. BMC Public Health. 2006;6:251-261. 
29. Lindström K, Elo A, Skogstad A, Dallner M, Gamberale F, Hottinen V, et al. User`s Guide for the QPSNordic. General Nordic Questionnaire for psychological and social factors at work. Copenhagen: TemaNord; 2000.

30. Johansson G, Lundberg O, Lundberg I. Return to work and adjustment latitude among employees on long-term sickness absence. J Occup Rehab. 2006;16:181-194.

31. Kristensen TS, Borritz M, Villadsen E, Christensen KB. The Copenhagen Burnout Inventory: A new tool for the assessment of burnout. Work Stress. 2005;19:192-197.

32. Baum A, Grunberg NE. Gender, stress and health. Health Psychol. 1991;10:80-85.

33. Roberts G. Age effects and health appraisal: A meta-analysis. J Gerontology. 1999;54B:S24-S30.

34. Härenstam A. Exploring gender, work and living conditions and health - suggestions for contextual and comprehensive approaches. Scand J Work Environ Health. 2009;35:127-135.

35. Östlin, P. Gender inequalities in health: The significance of work. In Wamala SP, Lynch J, eds. Gender and social inequities in health - a public health issue. Lund: Studentlitteratur; 2002:43-65.

36. DunlapWP, Xin X, Myers L. Computing aspects of power for multiple regression. Behav Res Methods Instruments Comput. 2004;36: 695-701.

37. Ware JE, Snow KK, Kosinski M, Gandek B. SF-36 Health Survey. Manual and Interpretation guide. Boston: The Health Institute, New England Medical Centre; 1993.

38. Hobson J, Beach JR. An investigation of the relationship between psychological health and workload among managers. Occup Med. 2000;50:518-522. 
39. Parasuraman S, Cleek MA. Coping behaviors and managers affective reactions to role stressors. J Vocat Behav. 1984;24:179-193.

40. Hultin H, Hallqvist J, Alexanderson K, et al. Low level of adjustment latitude - A risk factor for sickness absence. Europ J Public Health. 2010;20:682-688.

41. Allen TD, Herst DEL, Bruck CS, et al. Consequences associated with work-to-family conflict: A review and agenda for future research. J Occup Health Psychol. 2000;5:278308.

42. Kinnunen U, Mauno S. Antecedents and outcomes of work-family conflict among employed women and men in Finland. Hum Relations. 1998;51:157-177.

43. Mauno S, Kinnunen U, Ruokolainen M. Exploring work- and organization-based resources as moderators between work-family conflict, well-being, and job attitudes. Work Stress. 2006;20:210-233.

44. Styhre A, Josephson P-E. Revisiting site manager work: Stuck in the middle? Construction Manage Econ. 2006;24:521-528.

45. Parris MA, Vickers MH, Wilkes L. Caught in the middle. Organizational impediments to middle managers' work-life balance. Employee Responsibilities Rights J. 2008;20:101-117.

46. Bakker AB, Hakanen JJ, Demerouti E, Xanthopoulou D. Job resources boost work engagement, particularly when job demands are high. J Educ Psychol. 2007;99:284284. 
47. Johnson JV, Hall EM. Job strain, work place social support, and cardiovascular disease: A cross-sectional study of a random sample of the Swedish working population. Am J Public Health. 1988;78:1336-1342.

48. Sapp AL, Kawachi I, Sorensen G., LaMontagne AD, Subramanian SV. Does workplace social capital buffer the effects of job stress? A cross-sectional, multilevel analysis of cigarette smoking among U.S. manufacturing workers. J Occup Environ Med. 2010;52:740-750.

49. Oksanen T, Kuovonen A, Kivimäki M, Pentti J, Virtanen M, Linna A, et al. Social capital at work as a predictor of employee health: Multilevel evidence from work units in Finland. Social Sci Med. 2008;66:637-649.

50. Burt RS, Hogart RM, Michaud C. The social capital of French and American Managers. Organ Sci. 2000;11:123-147.

51. Ibarra H, Hunter M. How leaders create and use networks. Harvard Business Rev. 2007;85:40-47.

52. Kaplan RE. Trade routes: The manager's network of relationships. Organ Dynamics. 1984;11:37-52.

53. Dellve L, Wikström E. Managing complex workplace stress in health care organizations: Leaders' perceived legitimacy conflicts. J Nurs Manage. 2009;17:931941.

54. Veach TL, Rahe RH, Tolles RL, Newhall LM. Effectiveness of an intensive stress intervention workshop for senior managers. Stress Health. 2003;19:257-264. 
55. Li EY, Shani AB. Stress dynamics of information systems managers: A contingency model. J Manage Information Syst. 1991;7:107-130.

56. Moynihan DP, Pandey SK. Finding workable levers over work motivation: Comparing job satisfaction, job involvement, and organizational commitment. Adm Society. 2007;39:803-832.

57. Harris KJ, Kacmar KM. Easing the strain: The buffer role of supervisors in the perceptions of politics-strain relationship. J Occup Organ Psychol. 2005;78:337-354.

58. Skagert K, Dellve L, Eklöf M, Pousette A, Ahlborg Jr G. Leaders'strategies for dealing with own and their subordinates' stress in public human service organisations. Appl Ergonomics. 2008;39:803-811.

59. Erera-Weatherley PI. Coping with stress: Public welfare supervisors doing their best. Hum Relations. 1996;49:157-170.

60. Sundkvist Y, Zingmark K. Leading from intermediary positions: First-line administrators' experiences of their occupational role and situation. Scand J Occup Therapy. 2003;10:40-46.

61. Wong S-S, DeSanctis G, Staudenmayer N. The relationship between task interdependency and role stress: A revisit of the job demands - control model. $J$ Manage Studies. 2007;44:284-303.

62. Lee H, Cummings GG. Factors influencing job satisfaction of front line nurses: A systematic review. J Nurs Manage. 2008;16:768-783.

63. Persson O, Thylefors I. Career with no return: Roles, demands, and challenges as perceived by Swedish ward managers. Nurs Adm Quart. 1999;23:63-80. 
Investigating work conditions and burnout at three

64. Meyer RM, O’Brien-Pallas L, Doran D, Streiner D, Ferguson-Paré M, Duffield, C. Front-line managers as boundary spanners: Effects of span and time on nurse supervision satisfaction. J Nurs Manage. 2011;19:611-622.

65. Härenstam A, Karlqvist L, Bodin L, Nise G, Schéele P, The MOA Research Group. Patterns of working and living conditions: A holistic, multivariate approach to occupational health studies. Work Stress. 2003;17:73-92. 


\begin{tabular}{|c|c|c|c|c|c|c|}
\hline & & Subordinates & First-line & Middle & Total & $p$ \\
\hline & & & managers & managers & & \\
\hline & & $n(\%)$ & $n(\%)$ & $n(\%)$ & $n(\%)$ & \\
\hline \multirow[t]{2}{*}{ Sex } & Women & $2420(67)$ & $230(68)$ & $50(55)$ & $2700(66)$ & .055 \\
\hline & Men & $1215(33)$ & $108(32)$ & $41(45)$ & $1364(34)$ & \\
\hline \multirow[t]{5}{*}{ Age } & $18-30$ years & $290(8)$ & $21(6)$ & $4(4)$ & $315(8)$ & .082 \\
\hline & $31-40$ years & $744(21)$ & 63(19) & $20(22)$ & $827(21)$ & \\
\hline & $41-50$ years & 973(27) & 107(33) & $34(38)$ & $1114(28)$ & \\
\hline & $51-60$ years & $1117(32)$ & 108(33) & $25(28)$ & $1250(31)$ & \\
\hline & 61 years and older & $435(12)$ & 29(9) & $7(8)$ & $471(12)$ & \\
\hline \multirow[t]{3}{*}{ Education } & Primary & $305(8)$ & $16(5)$ & $3(3)$ & $324(8)$ & $<.001$ \\
\hline & Secondary & $1810(50)$ & $146(43)$ & $11(12)$ & 1967(48) & \\
\hline & University & $1515(42)$ & $178(52)$ & $77(85)$ & $1770(44)$ & \\
\hline
\end{tabular}


Table 2. Mean, standard deviation and bivariate correlations between the variables $(n=4069)$.

\begin{tabular}{|c|c|c|c|c|c|c|c|c|c|c|c|c|}
\hline 1.Demands & 13.68 & 2.94 & - & & & & & & & & & \\
\hline 2.Control & 18.05 & 2.85 & .02 & - & & & & & & & & \\
\hline 3.Social capital & 3.87 & 0.73 & $-.25 * *$ & $.23 * *$ & - & & & & & & & \\
\hline 4.Role clarity & 4.33 & 0.67 & $-15^{* *}$ & .02 & $.38 * *$ & - & & & & & & \\
\hline 5.Role conflict & 2.88 & 0.87 & $.53 * *$ & $-.09 * *$ & $-.36^{* *}$ & $-.25 * *$ & - & & & & & \\
\hline 6.Interactions between work and private life & 3.75 & 1.67 & $.43^{* *}$ & $.04 *$ & $-.27 * *$ & $-.23 * *$ & $.39 * *$ & - & & & & \\
\hline 7.Opportunities to work at a slower pace & 2.21 & 0.60 & $.23 * *$ & $-.17 * *$ & $-.13^{* *}$ & .00 & $.15^{* *}$ & $.09 * *$ & - & & & \\
\hline 8.Opportunities to shorten the workday & 2.29 & 0.61 & -.02 & $-.17 * *$ & $-.11 * *$ & $.09 * *$ & .02 & .02 & $.36 * *$ & - & & \\
\hline 9.Opportunities to get help from work colleagues & 1.86 & 0.65 & $.23^{* *}$ & .01 & $-30 * *$ & $-.19 * *$ & $.17 * *$ & $.22 * *$ & $.20 * *$ & $.07 * *$ & - & \\
\hline 10.Span of control & 13.13 & 12.57 & $.24 * *$ & $.12 *$ & -.05 & $-.10^{*}$ & $.11^{*}$ & .06 & .09 & -.04 & $.16^{* *}$ & - \\
\hline 11.Burnout & 35.87 & 18.00 & $.38 * *$ & $-.16^{* *}$ & $-.31 * *$ & $-.16 * *$ & $.35^{* *}$ & $.47 * *$ & $.11 * *$ & $.09 * *$ & $.15^{* *}$ & $.10^{*}$ \\
\hline
\end{tabular}

$* p<.05 ; * * p<.01$ 
Investigating work conditions and burnout at three

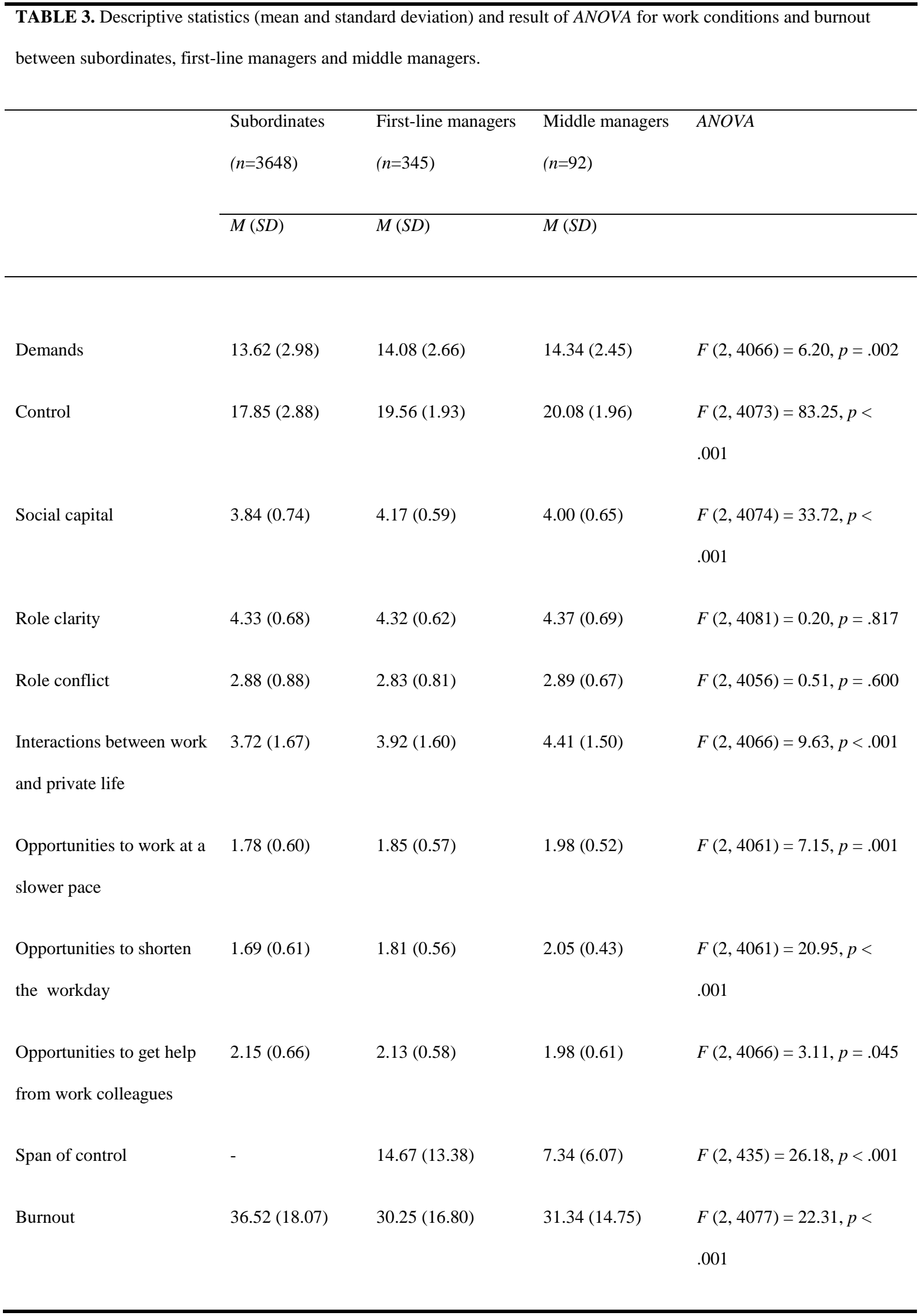


Investigating work conditions and burnout at three

TABLE 4. Multiple regression analysis of subordinates', first-line managers' and middle managers' burnout executed on work conditions $\left(R^{2}\right.$, standardized beta coefficient and $p$-value), adjusted for sex, age, education and organization/work group.

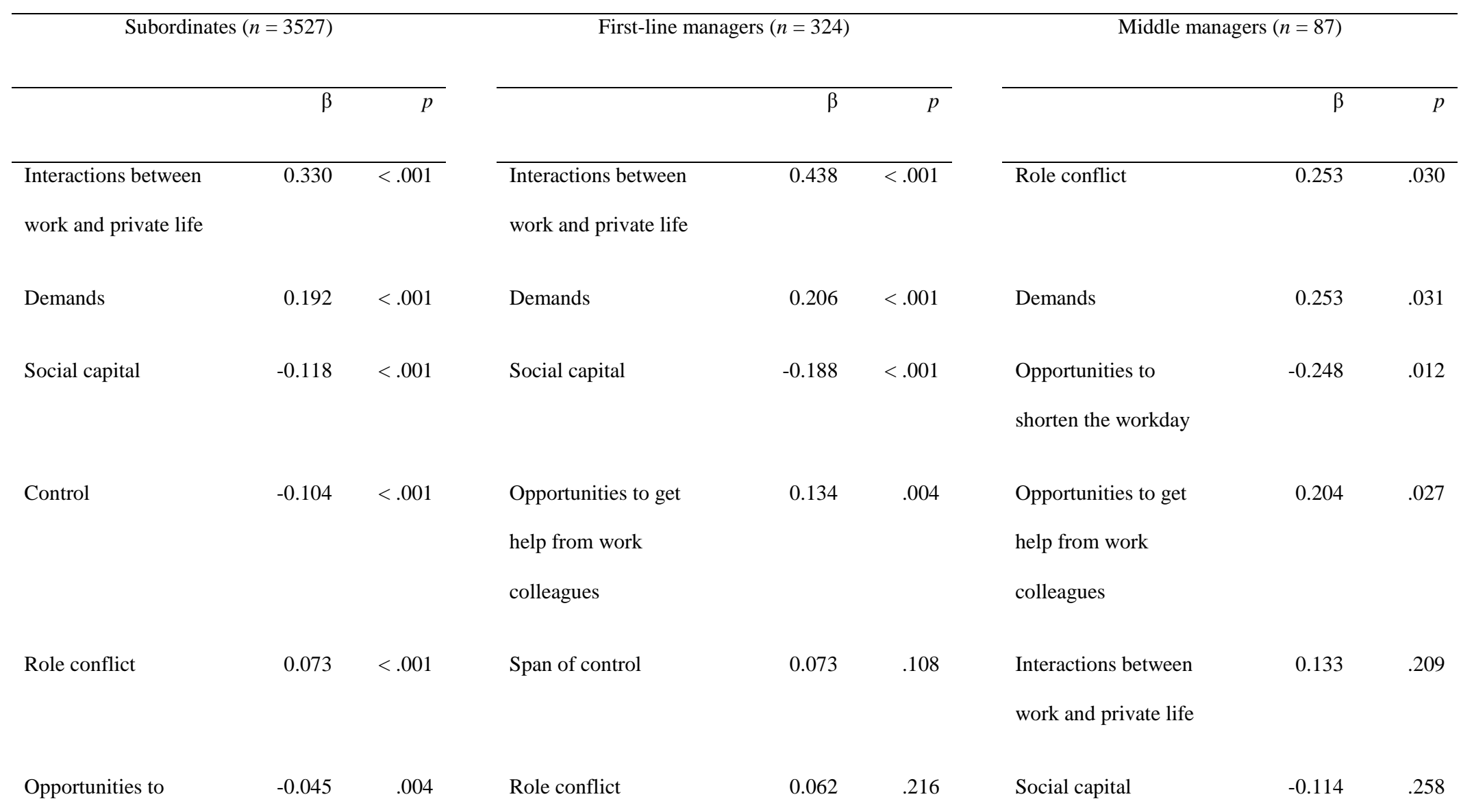

shorten the workday 
Investigating work conditions and burnout at three

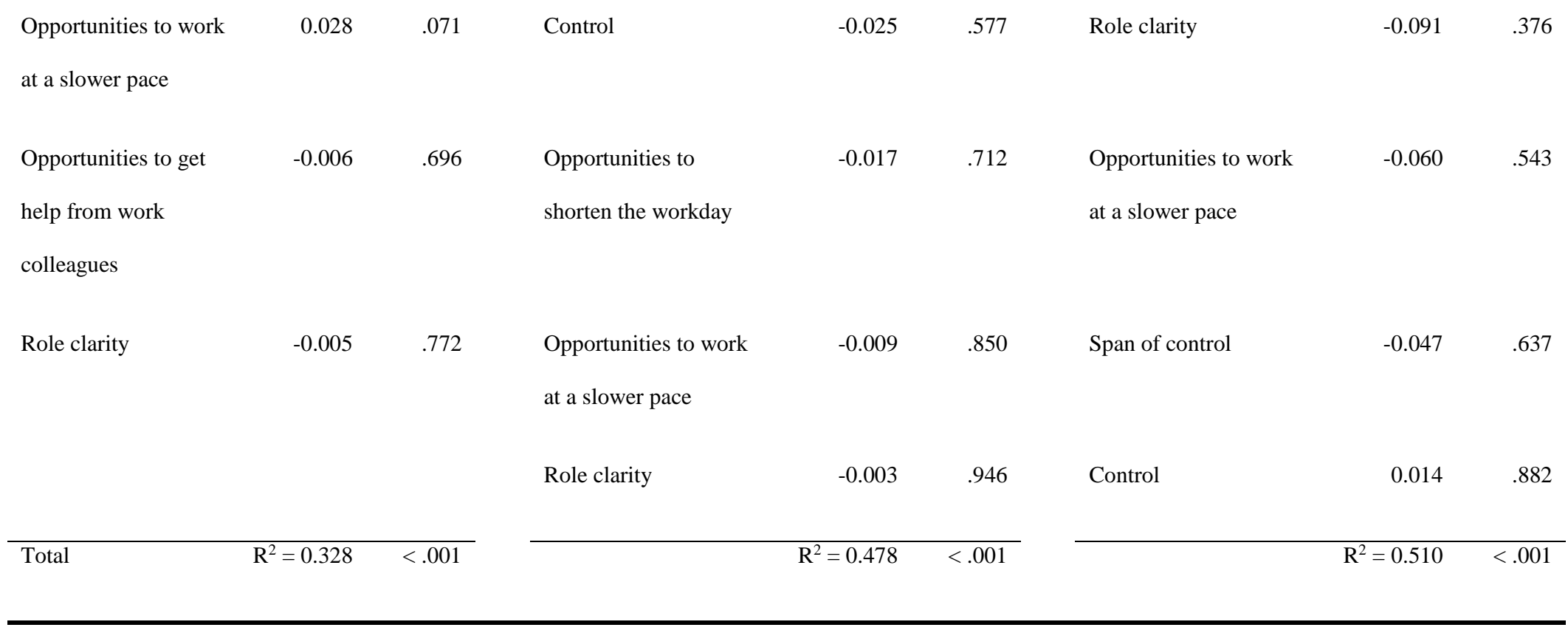

